\section{Antinuclear antibody as entry criterion for classification of systemic lupus erythematosus: pitfalls and opportunities}

Antinuclear antibodies (ANAs) are helpful to support the diagnosis of ANA-associated systemic rheumatic diseases (AASRD). Pisetsky et al recently reported on the variability of ANA detection, with differences observed between assay platforms (indirect immunofluorescence (IIF) vs solid phase) and kits in patients with established systemic lupus erythematosus (SLE). ${ }^{1}$ Variation of ANA detection has also been shown for automated IIF systems. ${ }^{2}$ Initiatives to better understand the variability of ANA tests are needed. ${ }^{3}$ Pisetsky et al ${ }^{1}$ also pointed out that ANA negativity occurs in established SLE, thereby complicating screening for patients for clinical trials. ${ }^{1}$ Yet, an Italian study reported a high sensitivity of ANA for established SLE. ${ }^{4}$

Testing for ANAs is complex and accurate interpretation of test results might be difficult. A task force of the European League Against Rheumatism (EULAR) has recently been installed that will address these issues in conjunction with other international committees. ${ }^{5}$ In this context and of particular interest is that new criteria for the classification of patients with SLE are being developed under the umbrellas of the EULAR and the American College of Rheumatology (ACR). ${ }^{6}$ In these criteria, a history of ANAs $\geq 1: 80$ by HEp-2 IIF will be the entry criterion (ie, must be present to be considered for classification as SLE). ${ }^{6}$ The $\geq 1: 80$ cut-off was chosen in order to ensure high sensitivity. ${ }^{6}$

We evaluated the performance of ANA for SLE diagnosis on 9851 unique consecutive patients tested for ANA (for description of the population, see Willems et $\left.a l^{7}\right)$. All patients were tested for ANA by IIF (HEp-2000; ImmunoConcepts) and by solid-phase assay (EliA CTD screen; Thermo Fisher). The clinical diagnosis was documented for 2475 patients, including (1) all patients who tested positive for IIF (cut-off $1: 80$ ) and/or CTD screen (cut-off ratio 0.7 ) and (2) a selection of 500 patients who tested double negative (including 150 patients with IIF titre $1: 40){ }^{7}$ This allowed us to calculate the positive predictive value (PPV) of IIF for SLE. As all samples were also tested by CTD screen, we could document SLE cases that tested negative by IIF but positive by CTD screen. Patients with SLE were divided into newly diagnosed SLE, established SLE and patients who did not fulfil the classification criteria. ${ }^{8}$

The titre-specific PPV of IIF 1:80 for SLE fulfilling the ACR classification criteria ${ }^{8}$ was $1 \%$, which is low and comparable with the estimated prevalence of SLE in the entire population $(0.9 \%)$. The estimated likelihood ratio (LR) associated with IIF 1:80 was 1.16 , indicating almost no difference in pretest to post-test probability. Of note, IIF 1:80 accounted for 37\% of all positive ANA IIF results. The titre-specific PPV for SLE increased with increasing antibody levels and was 3.5\%, 5.8\%, $8.7 \%, 11.8 \%$ and $16.8 \%$ for, respectively, IIF titre $1: 160$, $1: 320,1: 640, \geq 1: 1280$ and reactivity to overexpressed SSA on the HEp-2000 substrate. The estimated titre-specific LRs were, respectively, 4.1, 7.0, 10.8, 14.7 and 21.8. Newly diagnosed patients with SLE had IIF results $\geq 1: 160$, whereas $10 \%$ $(8 / 83)$ of patients with established SLE were IIF negative. Of note, six of the eight IIF-negative patients with established SLE tested positive with CTD screen.

ANAs are also associated with cutaneous lupus, mixed connective tissue disease (MCTD), systemic sclerosis (SSc),
Sjögren's syndrome (SS) and idiopathic inflammatory myopathy (IIM). The PPV for AASRD (SLE, SSc, SS, IIM, MCTD and cutaneous lupus) was $2 \%, 6.8 \%, 15 \%, 31.7 \%, 47.6 \%$ and $50 \%$ for, respectively, IIF 1:80, 1:160, 1:320, 1:640, $\geq 1: 1280$ and reactivity to the overexpressed SSA. Thus, SLE has to be distinguished from other AASRDs.

The PPV for SLE of IIF 1:80 combined with a positive CTD screen was 5.6\% (estimated LR: 6.8) compared with $1 \%$ for IIF $1: 80$ alone. It was $0.4 \%$ for IIF $1: 80$ combined with a negative CTD screen (estimated LR: 0.4). Similar findings (ie, increased PPV for double positivity and decreased PPV for singly positivity) were found when CTD screen was combined with higher IIF titres (see table 1 for an overview of the PPVs). For AASRD, an analogous increase in PPV was observed when IIF was combined with solid phase assay (see table 1 and Willems et $a l^{7}$ ).

Taken together, we found (1) that the titre-specific PPV of low-titre ANA for SLE is low, (2) that the PPV for SLE increases with increasing IIF titre and (3) that combining IIF with solid-phase assay adds value.

This implies that a low-positive ANA IIF titre $(1: 80)$ does not significantly increase the post-test probability for SLE (as the PPV is comparable with the PPV for the entire population tested for ANA). Thus, in those cases, classification will have to rely on clinical manifestations/characteristics. The downsides of the low PPV include potential false diagnoses and inappropriate treatment by clinicians not familiar with rheumatic diseases or inappropriate referrals to rheumatologists. It is important that clinicians are acquainted with the clinical manifestations/characteristics of SLE.

It is valuable to distinguish a low positive IIF titre $(1: 80)$ from a negative IIF result, as a negative result is useful to exclude SLE, whereas a low-positive result is not. It is also valuable to distinguish a low-positive IIF titre from a high-positive IIF titre, as a high titre has a higher PPV for SLE than a low titre. Therefore, an IIF result should not be seen as a dichotomous result (positive vs negative) but as a result with titre-specific LRs for disease. A potential danger of the new classification criteria is that clinicians not familiar with systemic rheumatic diseases will overestimate the PPV of a low-positive IIF ANA, as a cut-off of 1:80 is explicitly mentioned.

New classification criteria should recognise the high (but not absolute) negative predictive value of IIF and also that a low-positive IIF ANA has a lower PPV than a high-positive IIF ANA. Different weights could be assigned to an IIF result depending on the level of positivity. Furthermore, combining IIF with solid-phase assay can help to better stratify patients, especially in case of low-positive IIF titre. ${ }^{9-11}$

\footnotetext{
Philippe Willems, ${ }^{1}$ Ellen De Langhe, ${ }^{2}$ René Westhovens, ${ }^{3}$ Steven Vanderschueren, ${ }^{4}$ Daniel Blockmans, ${ }^{5}$ Xavier Bossuyt ${ }^{6}$

${ }^{1}$ Laboratory Medicine, University Hospitals Leuven, Leuven, Flanders, Belgium ${ }^{2}$ Rheumatology, University Hospitals Leuven, Leuven, Flanders, Belgium ${ }^{3}$ Rheumatology, University Hospitals Leuven, Leuven, Belgium

${ }^{4}$ General internal medicine, University Hospitals Leuven, Leuven, Belgium ${ }^{5}$ General internal medicine, University Hospitals Leuven, Leuven, Belgium ${ }^{6}$ Laboratory Medicine, University Hospitals Leuven, Leuven, Belgium
}

Correspondence to Dr Xavier Bossuyt, University Hospitals Leuven, Leuven, 3000, Belgium; xavier.bossuyt@uzleuven.be

Acknowledgements We thank Laura Hendrickx, Marie-Christine Clukkers and Silke Willebrords for expert technical assistance.

Contributors PW reviewed all the medical records of the patients included and performed the analysis. EDL, RW, SV and DB took care of the patients and helped with clinical classification of the patients. XB wrote a draft of the manuscript. All authors reviewed the draft and approved the submission of the manuscript. 
Table 1 Clinical diagnoses in patients tested for antinuclear antibodies (ANAs)

\begin{tabular}{|c|c|c|c|c|c|c|c|c|}
\hline Disease & $\begin{array}{l}\text { IIF } \\
\text { negative }\end{array}$ & $\begin{array}{l}\text { IIF } \\
1: 80\end{array}$ & $\begin{array}{l}\text { IIF } \\
1: 160\end{array}$ & $\begin{array}{l}\text { IIF } \\
1: 320\end{array}$ & $\begin{array}{l}\text { IIF } \\
1: 640\end{array}$ & $\begin{array}{l}\text { IIF } \\
\geq 1: 1280\end{array}$ & $\begin{array}{l}\text { IIF } \\
\text { SSA }\end{array}$ & Total \\
\hline $\begin{array}{l}\text { SLE } \\
\text { (newly diagnosed) }\end{array}$ & & & $\begin{array}{l}3 \\
(1,0,2)\end{array}$ & $\begin{array}{l}1 \\
(0,1,0)\end{array}$ & $\begin{array}{l}2 \\
(1,0,1)\end{array}$ & $\begin{array}{l}6 \\
(1,0,5)\end{array}$ & $\begin{array}{l}3 \\
(0,0,3)\end{array}$ & 15 \\
\hline $\begin{array}{l}\text { SLE } \\
\text { (established) }\end{array}$ & $\begin{array}{l}8 \\
(2,0,6)\end{array}$ & $\begin{array}{l}6 \\
(2,1,3)\end{array}$ & $\begin{array}{l}14 \\
(8,0,6)\end{array}$ & $\begin{array}{l}11 \\
(4,2,5)\end{array}$ & $\begin{array}{l}7 \\
(2,0,5)\end{array}$ & $\begin{array}{l}6 \\
(0,0,6)\end{array}$ & $\begin{array}{l}16 \\
(0,0,16)\end{array}$ & 68 \\
\hline $\begin{array}{l}\text { SLE } \\
\text { (not fulfilling classification criteria) }\end{array}$ & $\begin{array}{l}6 \\
(3,2,1)\end{array}$ & $\begin{array}{l}2 \\
(0,0,2)\end{array}$ & $\begin{array}{l}2 \\
(2,0,0)\end{array}$ & $\begin{array}{l}1 \\
(0,0,1)\end{array}$ & $\begin{array}{l}1 \\
(1,0,0)\end{array}$ & $\begin{array}{l}3 \\
(1,1,1)\end{array}$ & $\begin{array}{l}5 \\
(0,0,5)\end{array}$ & 20 \\
\hline Cutaneous lupus & $\begin{array}{l}4 \\
(4,0,0)\end{array}$ & $\begin{array}{l}3 \\
(1,0,2)\end{array}$ & $\begin{array}{l}4 \\
(2,0,2)\end{array}$ & $\begin{array}{l}1 \\
(1,0,0)\end{array}$ & & & $\begin{array}{l}10 \\
(0,0,10)\end{array}$ & 22 \\
\hline $\begin{array}{l}\text { Systemic sclerosis } \\
\text { (newly diagnosed) }\end{array}$ & & & $\begin{array}{l}3 \\
(1,0,2)\end{array}$ & $\begin{array}{l}5 \\
(0,0,5)\end{array}$ & $\begin{array}{l}9 \\
(2,0,7)\end{array}$ & $\begin{array}{l}19 \\
(3,0,16)\end{array}$ & & 36 \\
\hline $\begin{array}{l}\text { Systemic sclerosis } \\
\text { (established) }\end{array}$ & & & $\begin{array}{l}5 \\
(1,0,4)\end{array}$ & $\begin{array}{l}5 \\
(1,1,3)\end{array}$ & $\begin{array}{l}11 \\
(0,0,11)\end{array}$ & $\begin{array}{l}6 \\
(1,0,5)\end{array}$ & & 27 \\
\hline $\begin{array}{l}\text { Systemic sclerosis } \\
\text { (not fulfilling classification criteria) }\end{array}$ & $\begin{array}{l}1 \\
(0,1,0)\end{array}$ & $\begin{array}{l}3 \\
(3,0,0)\end{array}$ & $\begin{array}{l}1 \\
(0,0,1)\end{array}$ & $\begin{array}{l}2 \\
(0,0,2)\end{array}$ & $\begin{array}{l}4 \\
(0,0,4)\end{array}$ & $\begin{array}{l}2 \\
(1,0,1)\end{array}$ & $\begin{array}{l}1 \\
(0,0,1)\end{array}$ & 14 \\
\hline $\begin{array}{l}\text { Polymyositis/dermatomyositis } \\
\text { (newly diagnosed) }\end{array}$ & $\begin{array}{l}2 \\
(0,0,2)\end{array}$ & & $\begin{array}{l}1 \\
(0,0,1)\end{array}$ & $\begin{array}{l}2 \\
(1,1,0)\end{array}$ & $\begin{array}{l}2 \\
(1,0,1)\end{array}$ & $\begin{array}{l}2 \\
(0,0,2)\end{array}$ & & 9 \\
\hline $\begin{array}{l}\text { Polymyositis/dermatomyositis } \\
\text { (established) }\end{array}$ & & & $\begin{array}{l}1 \\
(1,0,0)\end{array}$ & $\begin{array}{l}2 \\
(1,1,0)\end{array}$ & $\begin{array}{l}1 \\
(0,0,1)\end{array}$ & $\begin{array}{l}3 \\
(1,1,1)\end{array}$ & $\begin{array}{l}1 \\
(0,0,1)\end{array}$ & 8 \\
\hline $\begin{array}{l}\text { Polymyositis/dermatomyositis } \\
\text { (not fulfilling classification criteria) }\end{array}$ & $\begin{array}{l}2 \\
(0,0,2)\end{array}$ & $\begin{array}{l}1 \\
(0,1,0)\end{array}$ & $\begin{array}{l}2 \\
(2,0,0)\end{array}$ & $\begin{array}{l}4 \\
(3,0,1)\end{array}$ & $\begin{array}{l}2 \\
(0,0,2)\end{array}$ & & $\begin{array}{l}1 \\
(0,0,1)\end{array}$ & 12 \\
\hline $\begin{array}{l}\text { Sjögren's syndrome } \\
\text { (newly diagnosed) }\end{array}$ & $\begin{array}{l}4 \\
(0,0,4)\end{array}$ & $\begin{array}{l}1 \\
(0,0,1)\end{array}$ & & & & $\begin{array}{l}1 \\
(0,0,1)\end{array}$ & $\begin{array}{l}13 \\
(0,0,13)\end{array}$ & 19 \\
\hline $\begin{array}{l}\text { Sjögren } \\
\text { (established) }\end{array}$ & $\begin{array}{l}2 \\
(0,1,1)\end{array}$ & $\begin{array}{l}2 \\
(2,0,0)\end{array}$ & $\begin{array}{l}1 \\
(0,0,1)\end{array}$ & $\begin{array}{l}3 \\
(0,0,3)\end{array}$ & $\begin{array}{l}1 \\
(0,0,1)\end{array}$ & $\begin{array}{l}1 \\
(0,0,1)\end{array}$ & $\begin{array}{l}16 \\
(0,0,16)\end{array}$ & 26 \\
\hline $\begin{array}{l}\text { Sjögren } \\
\text { (not fulfilling classification criteria) }\end{array}$ & $\begin{array}{l}2 \\
(1,1,0)\end{array}$ & $\begin{array}{l}1 \\
(1,0,0)\end{array}$ & & & & & $\begin{array}{l}1 \\
(0,0,1)\end{array}$ & 4 \\
\hline $\begin{array}{l}\text { Mixed connective tissue disease } \\
\text { (newly diagnosed) }\end{array}$ & & & & & & $\begin{array}{l}4 \\
(0,0,4)\end{array}$ & & 4 \\
\hline $\begin{array}{l}\text { Mixed connective tissue disease } \\
\text { (established) }\end{array}$ & & & $\begin{array}{l}1 \\
(0,0,1)\end{array}$ & $\begin{array}{l}1 \\
(0,0,1)\end{array}$ & & $\begin{array}{l}2 \\
(0,0,2)\end{array}$ & & 4 \\
\hline $\begin{array}{l}\text { Mixed connective tissue disease } \\
\text { (not fulfilling classification criteria) }\end{array}$ & & & $\begin{array}{l}1 \\
(0,1,0)\end{array}$ & & & $\begin{array}{l}3 \\
(0,0,3)\end{array}$ & & 4 \\
\hline Not differentiated (doubtful) & $\begin{array}{l}1 \\
(1,0,0)\end{array}$ & & $\begin{array}{l}3 \\
(3,0,0)\end{array}$ & $\begin{array}{l}2 \\
(1,1)\end{array}$ & $\begin{array}{l}1 \\
(1,0,0)\end{array}$ & & $\begin{array}{l}1 \\
(0,0,1)\end{array}$ & 8 \\
\hline Non-AASRD & $\begin{array}{l}47 \\
(30,3,14)\end{array}$ & $\begin{array}{l}30 \\
(22,0,8)\end{array}$ & $\begin{array}{l}18 \\
(17,01)\end{array}$ & $\begin{array}{l}8 \\
(6,0,2)\end{array}$ & $\begin{array}{l}2 \\
(1,0,1)\end{array}$ & $\begin{array}{l}2 \\
(2,0,0)\end{array}$ & $\begin{array}{l}3 \\
(0,0,3)\end{array}$ & 110 \\
\hline Rheumatic disease & $\begin{array}{l}49 \\
(25,11,13)\end{array}$ & $\begin{array}{l}42 \\
(37,1,4)\end{array}$ & $\begin{array}{l}52 \\
(48,0,4)\end{array}$ & $\begin{array}{l}23 \\
(20,1,2)\end{array}$ & $\begin{array}{l}6 \\
(5,1,0)\end{array}$ & $\begin{array}{l}4 \\
(4,0,0)\end{array}$ & $\begin{array}{l}7 \\
(0,0,7)\end{array}$ & 183 \\
\hline Inflammatory disease & $\begin{array}{l}76 \\
(39,15,22)\end{array}$ & $\begin{array}{l}64 \\
(54,4,6)\end{array}$ & $\begin{array}{l}44 \\
(37,2,5)\end{array}$ & $\begin{array}{l}27 \\
(3,15,9)\end{array}$ & $\begin{array}{l}12 \\
(10,1,1)\end{array}$ & $\begin{array}{l}12 \\
(10,, 2)\end{array}$ & $\begin{array}{l}6 \\
(0,0,6)\end{array}$ & 241 \\
\hline No inflammatory disease & $\begin{array}{l}655 \\
(395,96,164)\end{array}$ & $\begin{array}{l}439 \\
(399,10,30)\end{array}$ & $\begin{array}{l}332 \\
(296,13,23)\end{array}$ & $\begin{array}{l}109 \\
(92,9,8)\end{array}$ & $\begin{array}{l}43 \\
(33,4,6)\end{array}$ & $\begin{array}{l}29 \\
(18,1,10)\end{array}$ & $\begin{array}{l}34 \\
(4,2,28)\end{array}$ & 1641 \\
\hline Total & $\begin{array}{l}859 \\
(500,130,229)\end{array}$ & $\begin{array}{l}594 \\
(521,17,56)\end{array}$ & $\begin{array}{l}488 \\
(419,16,53)\end{array}$ & $\begin{array}{l}207 \\
(145,19,43)\end{array}$ & $\begin{array}{l}104 \\
(56,5,43)\end{array}$ & $\begin{array}{l}105 \\
(42,4,59)\end{array}$ & $\begin{array}{l}118 \\
(4,2,112)\end{array}$ & 2475 \\
\hline \multicolumn{9}{|l|}{ Positive predictive values (PPVs) } \\
\hline PPV of IIF for SLE & 0.001 & 0.010 & 0.035 & 0.058 & 0.087 & 0.118 & 0.168 & \\
\hline PPV of IIF/EliA(-) SLE & & 0.004 & 0.022 & 0.028 & 0.055 & 0.024 & & \\
\hline PPV of IIF/EliA $(+)^{*}$ SLE & & 0.056 & 0.116 & 0.131 & 0.125 & 0.180 & 0.174 & \\
\hline PPV of IIF for AASRD & & 0.020 & 0.069 & 0.157 & 0.344 & 0.515 & 0.541 & \\
\hline PPV of IIF/EliA(-) for AASRD & & 0.010 & 0.034 & 0.057 & 0.109 & 0.150 & & \\
\hline PPV of IIF/EliA $(+)^{*}$ for AASRD & 0.040 & 0.100 & 0.284 & 0.404 & 0.659 & 0.772 & 0.562 & \\
\hline PPV of IIF/EliA(+) † for AASRD & 0.058 & 0.111 & 0.365 & 0.447 & 0.750 & 0.796 & 0.573 & \\
\hline \multicolumn{9}{|l|}{ Estimated likelihood ratios (LRs) } \\
\hline Estimated LR of IIF for SLE & 0.096 & 1.2 & 4.1 & 7.0 & 10.9 & 15.1 & 23.0 & \\
\hline Estimated LR of IIF/EliA(-) for SLE & & 0.44 & 2.5 & 3.2 & 6.6 & 2.8 & & \\
\hline Estimated LR of IIF/EliA(+) for SLE & & 6.8 & 14.9 & 17.1 & 16.2 & 25.0 & 24.0 & \\
\hline
\end{tabular}

9851 consecutive patients were tested for ANA by indirect immunofluorescence (IIF) (HEp-2000; ImmunoConcepts) and by solid phase (EliA CTD screen, detecting antibodies to dsDNA, SSA/Ro 52, SSA/Ro 60, SSB/La, U1-RNP (RNP-70, A, C), Sm, Jo-1, SCl-70, CENP, fibrillarin, RNA POI III, PM-SCl, Mi-2, Rib-P and PCNA). The table gives an overview of the clinical diagnoses and the test results in consecutive patients who tested positive for ANA by IIF and/or CTD screen and in a selection on 500 patients who tested negative by both assays (total $n=2475 ; 325$ patients were excluded because there were insufficient data for proper clinical categorisation). The values indicate the number of patients with a particular IIF result. The values in parentheses indicate the number of patients who tested negative (first number), equivocal (second number) or positive (third number) with CTD screen. The population has been described in Willems et al. ${ }^{7}$ Non-AASRD (non-ANA-associated systemic rheumatic disease) includes, for example, different types of vasculitis, polymyalgia rheumatica and sarcoidosis. Rheumatic diseases include, for example, rheumatoid arthritis and psoriatic arthritis. Inflammatory diseases include, for example, colitis ulcerosa, Crohn's disease, autoimmune hepatitis, autoimmune thyroiditis, psoriasis and immune thrombocytopenic purpura.

Newly diagnosed: tested on a diagnostic sample (ie, at the time of diagnosis).

Established: tested on a follow-up sample (most of these patients had received immunosuppressive therapy and had been diagnosed in another centre).

Not fulfilling classification criteria: the clinician strongly considered the presence of an AASRD and initiated immunosuppressive therapy, but the patient did not fulfil the classification criteria. For description of the classification criteria,

see Willems et al.

For the estimation of the PPV of a negative IIF result for systemic lupus erythematosus (SLE), we only took into account the SLE cases documented (1) in the patients who were single positive for CTD screen and (2) in a selection of 500 patients who were negative for IIF and CTD screen. This probably is an underestimation as we did not check the medical records of all double-negative patients. Patients with AASRD were checked whether they fulfilled the classification criteria of Sjögren's syndrome, systemic sclerosis, dermatomyositis/polymyositis, mixed connective tissue disease and SLE as described in Willems et al.' For estimation of the PPV, we excluded patients who did not fulfil the classification criteria. For estimation of the PPV for AASRD, we included cutaneous lupus as an AASRD.

*Including equivocal results.

tExcluding equivocal results. 
Funding This work was supported by Thermo Fisher.

Competing interests $\mathrm{XB}$ has received lecture fees from and has been a consultant for Thermo Fisher.

Patient consent for publication Not required.

Ethics approval Ethics committee of the University Hospitals Leuven.

Provenance and peer review Not commissioned; internally peer reviewed.

(c) Article author(s) (or their employer(s) unless otherwise stated in the text of the article) 2019. All rights reserved. No commercial use is permitted unless otherwise expressly granted.

\section{(A) Check for updates}

To cite Willems P, De Langhe E, Westhovens R, et al. Ann Rheum Dis 2019;78:e76.

Received 24 May 2018

Accepted 27 May 2018

Published Online First 23 June 2018

\section{(5) Linked}

http://dx.doi.org/10.1136/annrheumdis-2018-213841

Ann Rheum Dis 2019;78:e76. doi:10.1136/annrheumdis-2018-213821

\section{REFERENCES}

1 Pisetsky DS, Spencer DM, Lipsky PE, et al. Assay variation in the detection of antinuclear antibodies in the sera of patients with established SLE. Ann Rheum Dis 2018:77:911-3.
2 Van Hoovels L, Schouwers S, Van den Bremt S, et al. Variation in antinuclear antibody detection by automated indirect immunofluorescence analysis. Ann Rheum Dis 2019;78:e48.

3 Mahler M. Lack of standardisation of ANA and implications for drug development and precision medicine. Ann Rheum Dis 2019;78:e33.

4 Pregnolato F, Borghi MO, Meroni PL. Forum Interdisciplinare per la Ricerca sulle Malattie Autoimmuni (FIRMA) Study Group. Pitfalls of antinuclear antibody detection in systemic lupus erythematosus: the positive experience of a national multicentre study. Ann Rheum Dis 2019;78:e50.

5 Meroni PL, Chan EK, Damoiseaux J, et al. members of the committees. Unending story of the indirect immunofluorescence assay on HEp-2 cells: old problems and new solutions? Ann Rheum Dis 2019;78:e46.

6 Tedeschi SK, Johnson SR, Boumpas D, et al. Developing and refining new candidate criteria for systemic lupus erythematosus classification: an international collaboration. Arthritis Care Res 2018:70:571-81.

7 Willems P, De Langhe E, Claessens J, et al. Screening for connective tissue disease-associated antibodies by automated immunoassay. Clin Chem Lab Med 2018;56:909-18.

8 Hochberg MC. Updating the American College of Rheumatology revised criteria for the classification of systemic lupus erythematosus. Arthritis Rheum 1997;40:1725.

9 Claessens J, Belmondo T, De Langhe E, et al. Solid phase assays versus automated indirect immunofluorescence for detection of antinuclear antibodies. Autoimmun Rev 2018; 17:533-40.

10 Bizzaro N, Brusca I, Previtali G, et al. The association of solid-phase assays to immunofluorescence increases the diagnostic accuracy for ANA screening in patients with autoimmune rheumatic diseases. Autoimmun Rev 2018:17:541-7.

11 Bossuyt $X$, Fieuws S. Detection of antinuclear antibodies: added value of solid phase assay? Ann Rheum Dis 2014:73:e10. 